\title{
Socio-Demographic Determinants of Satisfaction with Training Process among Final Year Nursing Students at Kenya Medical Training College
}

Kabanya $\mathrm{CN}^{*}$, Karani AK and Mirie W

Kenya Medical Training College, University of Nairobi, Embu, Kenya

*Corresponding author: Kabanya CN, Kenya Medical Training College, University of Nairobi, Embu, Kenya, Tel: 2540722432372; E-mail: ckabanya@kmtc.ac.ke

Received data: Nov 03, 2016, Accepted date: Jan 06, 2017, Published date: Jan 13, 2017

Copyright: (c) 2017 Kabanya CN, et al. This is an open-access article distributed under the terms of the Creative Commons Attribution License, which permits unrestricted use, distribution, and reproduction in any medium, provided the original author and source are credited.

\begin{abstract}
Student satisfaction is an important means of assessing the institution's capacity in meeting the students' learning needs. The degree of student's satisfaction with their educational experience is an important dimension in the assessment of institutional effectiveness. Understanding students' perceptions and satisfaction is important in efforts to enrich the students' learning experiences. This study aimed at identifying the student's socio-demographic factors that influenced satisfaction with the nursing training among the final year nursing students in Kenya Medical Training College. This was a mixed method design where both quantitative and qualitative data was collected using the following; a self-administered questionnaire comprising of both closed and open ended questions and a Likert's rating scale which scored the levels of satisfaction on various themes. Data was collected from final year nursing students in the six selected campuses. Quantitative data was analyzed using Statistical Package for Social Scientists (SPSS) program version 20.0. Chi-square tests were used to test relationships between perceived level of satisfaction and the selected independent variables. The results showed that gender of student did not influence students overall satisfaction. However, students who had positive college experience were satisfied with overall teaching and learning process. Student's information sources regarding the nursing career had a significant association with their satisfaction with teaching and learning process.
\end{abstract}

Keywords: Satisfaction; Teaching and learning; Extra-curricular activities; Nursing training

\section{Introduction}

Satisfaction is the good feeling that one has when she/he achieves something or when something she/he wanted to happen does happen. Jaradeen et al. [1] defined satisfaction as a psychological state which results from confirmation of expectations with reality. Studies point out that certain factors exert positive and significant influences on student satisfaction. These factors include, student background characteristics, participation in the community, access to and use of college facilities and services, faculty style of instruction, academic and social integration, learning activities, courses, quality and usefulness of education [2,3]. A study done by Rognstad [4], found that Norwegian nursing students were motivated to join a nursing career by the need for human contact and need for helping others. They viewed nursing as a vocation and felt compelled to do it. They felt a strong desire to care for people and make a difference. Zysberg and Berry [5] argued that there is a deep and rewarding joy in caring for people.

Student's satisfaction contributes to intellectual, social, affective growth, classroom and college retention, academic performance, motivation and college persistence [2]. Satisfied students are more successful and dedicated to accomplish their goals than unsatisfied students [2,6]. A study done by Jaradeen et al. [1] found out that students were satisfied with the syllabus and grading method. They were also satisfied that nursing courses were helping them on how to care for their families, and how to communicate effectively. However, they were dissatisfied with college facilities, acquiring writing, critical thinking and problem solving skills. Studies done found a significant relationship between the clinical placement setting and overall satisfaction where students who completed their clinical placement in a community setting expressed higher levels of satisfaction than their counterparts from bed based services [7,8]. The study by Happel [8] further showed that there was overall sense of satisfaction by student nurses with their clinical experience where eighty-eight percent of students enjoyed their clinical placement. They indicated that they felt welcomed, well supported and orientated, involved in patients care and regarded the nursing staff as highly skilled and respectful to patients [8]. Their relationship with the clinical supervisors increased their motivation to learn more.

Ansari [9] found out that student's socio-demographic characteristics affected their satisfaction where students with a higher average age were more satisfied than the younger ones. It was also determined that handicapped students were a little more satisfied than the others. Ansari [9] also found out that satisfaction varies from program to program and from one institution to another.

\section{Objective of the Study}

The aim of the study was to determine students' socio-demographic factors that influence level of satisfaction with the training process among final year nursing students at the Kenya Medical Training College.

\section{Research design}

A mixed method was used which involved both quantitative and qualitative method. 
Citation: Kabanya CN, Karani AK, Mirie W (2017) Socio-Demographic Determinants of Satisfaction with Training Process among Final Year Nursing Students at Kenya Medical Training College. Adv Practice Nurs 2: 128. doi:10.4172/2573-0347.1000128

Page 2 of 6

\section{Sampling}

A sample size of 341 final year students was computed using the formula as used by Fischer et al. Three hundred (300) students who consented to be included in the study filled the questionnaire.

\section{Data analysis}

Data was processed stepwise and involved data validation, cleaning, coding and entry into Statistical Package for Social Sciences (SPSS) version 20.0 in order to generate quantitative and qualitative results. Descriptive statistics were computed to generate means, percentages, ranges and standard deviation and the results presented in form of frequency tables, bar graphs and narration.

Inferential statistics were generated using Pearson's coefficient and Chi-square test in order to determine the relationship between student factors and level of satisfaction with training. The level of significance was set at $\mathrm{P}<0.05$. Logistic regression model was also be used to analyze the predictors of satisfaction.

\section{Results}

Students' gender, religion and marital status were established. Majority of the students were females (62.8\%). Most of these students were protestants $(53.7 \%), 36.3 \%$ were catholic faithful and $2.0 \%$ were Muslims. $84.7 \%$ of these students were single whereas $14.3 \%$ were married students (Table 1).

\begin{tabular}{|l|l|l|}
\hline Demographic information & Number of students (N=300) & Percent \\
\hline Gender & & \\
\hline Male & 112 & 37.3 \\
\hline Female & 188 & 62.8 \\
\hline Religion & & \\
\hline Catholic & 109 & 36.3 \\
\hline Protestant & 161 & 53.7 \\
\hline Muslims & 6 & 2.0 \\
\hline Others & 24 & 8.0 \\
\hline Marital status & 1 & 84.7 \\
\hline Married & 254 & 0.7 \\
\hline Separated & 2 & 14.3 \\
\hline Single & 13 & 0.3 \\
\hline Widowed & 254 & \\
\hline
\end{tabular}

Table 1: Demographic information of the students

\section{Parents' demographic information}

The parents' education levels and occupation established showed that, $41.7 \%$ of these students were from homes where the father had college education. $16.3 \%$ stated that their fathers had university education while $1.3 \%$ of the students had their fathers having vocational education. When asked to about their mothers' education,
$35.7 \%$ of the students stated their mothers had college education, $6.0 \%$ had the mothers having university education.

\section{Occupation of the parents}

Majority of the students $39.3 \%$ were from homes where the fathers were salaried, $32.75 \%$ were from homes where the fathers were farmers and $22.3 \%$ were from homes headed by business fathers. The mothers were mainly farmers (41.0\%). $26.7 \%$ of the students had salaried mothers whereas $24.0 \%$ of the students had business mothers (Table 2).

\begin{tabular}{|c|c|c|}
\hline $\begin{array}{l}\text { Demographic information of } \\
\text { parents }\end{array}$ & $\begin{array}{l}\text { Number of students } \\
(\mathrm{N}=300)\end{array}$ & $\begin{array}{l}\text { Percent } \\
(\%)\end{array}$ \\
\hline \multicolumn{3}{|l|}{ Fathers' education level } \\
\hline Primary & 49 & 16.3 \\
\hline Secondary & 58 & 19.3 \\
\hline Vocational & 4 & 1.3 \\
\hline College & 125 & 41.7 \\
\hline University & 49 & 16.3 \\
\hline Others & 15 & 5.0 \\
\hline \multicolumn{3}{|l|}{ Mothers education level } \\
\hline Primary & 75 & 25.0 \\
\hline Secondary & 81 & 27.0 \\
\hline Vocational & 9 & 3.0 \\
\hline College & 107 & 35.7 \\
\hline University & 18 & 6.0 \\
\hline Others & 10 & 3.3 \\
\hline \multicolumn{3}{|l|}{ Fathers' occupation } \\
\hline Farmer & 98 & 32.7 \\
\hline Salaried employee & 118 & 39.3 \\
\hline Business & 67 & 22.3 \\
\hline Unskilled laborer & 6 & 2.0 \\
\hline Others & 11 & 3.7 \\
\hline \multicolumn{3}{|l|}{ Mothers occupation } \\
\hline Farmer & 123 & 41.0 \\
\hline Salaried employee & 80 & 26.7 \\
\hline Business & 72 & 24.0 \\
\hline Unskilled laborer & 17 & 5.7 \\
\hline Others & 8 & 2.7 \\
\hline
\end{tabular}

Table 2: Parents education levels and occupation. 
Citation: Kabanya CN, Karani AK, Mirie W (2017) Socio-Demographic Determinants of Satisfaction with Training Process among Final Year Nursing Students at Kenya Medical Training College. Adv Practice Nurs 2: 128. doi:10.4172/2573-0347.1000128

Page 3 of 6

\section{Student factors that influence levels of satisfaction with nursing training}

Kenya certificate of secondary education (KCSE) grades obtained by the students

In their KCSE, majority of the students in the nursing colleges had obtained KCSE grade B- (minus). 47.7\% obtained grade B-, $28.0 \%$ obtained KCSE grade $\mathrm{C}+, 10.3 \%$ had obtained grade $\mathrm{B}+$ while the highest grade obtained was KCSE grade A- which was obtained by $3.7 \%$ of the students (Table 3 ).

\begin{tabular}{|l|l|l|}
\hline KCSE grades obtained & Number of students $\mathbf{( N = 3 0 0 )}$ & Percent $(\%)$ \\
\hline Grade A- & 3 & 1 \\
\hline Grade B+ & 31 & 10.3 \\
\hline Grade B & 12 & 4 \\
\hline Grade B- & 143 & 47.7 \\
\hline Grade C+ & 84 & 28 \\
\hline Grade C & 16 & 5.3 \\
\hline None committal & 11 & 3.7 \\
\hline
\end{tabular}

Table 3: KCSE grades obtained by the students.

\section{Effect of the KCSE result on the students overall satisfaction with the teaching process of the nursing program}

Chi square test for association was conducted on the students' performance in KCSE and the levels of their satisfaction with the teaching and learning process of nursing. All the students who had obtained KCSE grade A- were somehow satisfied with the teaching and learning process of the nursing program. Majority of those who had B(67.2\%), grade B (66.7\%), grade B+ $(51.7 \%)$, grade $C(50.0 \%)$, grade $C$ $+(75.9 \%)$ were satisfied with the teaching and learning process. The result showed that there was no significant variation in students satisfaction with the KCSE grades obtained $(\chi 2=23.53, \mathrm{P}=0.171)$ (Table $4)$.

\begin{tabular}{|l|l|l|l|l|l|l|}
\hline \multirow{2}{*}{$\begin{array}{l}\text { KCSE } \\
\text { grade } \\
\text { obtained }\end{array}$} & & \multicolumn{3}{|c|}{$\begin{array}{l}\text { Overall satisfaction with the teaching and } \\
\text { learning process of the nursing program }\end{array}$} & Total \\
\cline { 3 - 7 } & & $\begin{array}{l}\text { Not } \\
\text { satisfied }\end{array}$ & $\begin{array}{l}\text { Somehow } \\
\text { satisfied }\end{array}$ & Satisfied & $\begin{array}{l}\text { Extremely } \\
\text { satisfied }\end{array}$ & \\
\hline \multirow{2}{*}{ A- } & Count & 0 & 2 & 0 & 0 & 2 \\
\cline { 2 - 7 } & $0.00 \%$ & $100.00 \%$ & $0.00 \%$ & $0.00 \%$ & $100.00 \%$ & \\
\hline \multirow{2}{*}{ B- } & Count & 2 & 32 & 90 & 10 & 134 \\
\cline { 2 - 7 } & $1.50 \%$ & $23.90 \%$ & $67.20 \%$ & $7.50 \%$ & $100.00 \%$ & \\
\hline B & Count & 0 & 4 & 8 & 0 & 12 \\
\cline { 2 - 7 } & $0.00 \%$ & $33.30 \%$ & $66.70 \%$ & $0.00 \%$ & $100.00 \%$ & \\
\hline \multirow{2}{*}{ B+ } & Count & 0 & 12 & 15 & 2 & 29 \\
\cline { 2 - 7 } & $0.00 \%$ & $41.40 \%$ & $51.70 \%$ & $6.90 \%$ & $100.00 \%$ & \\
\hline \multirow{2}{*}{ C } & Count & 0 & 5 & 8 & 3 & 16 \\
\cline { 2 - 7 } & $0.00 \%$ & $31.30 \%$ & $50.00 \%$ & $18.80 \%$ & $100.00 \%$ & \\
\hline C+ & Count & 0 & 16 & 60 & 3 & 79 \\
\cline { 2 - 7 } & $0.00 \%$ & $20.30 \%$ & $75.90 \%$ & $3.80 \%$ & $100.00 \%$ & \\
\hline \multirow{2}{*}{ Total } & Count & 2 & 72 & 191 & 18 & 283 \\
\cline { 2 - 7 } & $0.70 \%$ & $25.40 \%$ & $67.50 \%$ & $6.40 \%$ & $100.00 \%$ & \\
\hline
\end{tabular}

Table 4: Students' KCSE performance and the level of satisfaction with the teaching process of nursing program.

\section{Students' gender and satisfaction with teaching and learning program}

The gender of the students did not affect their overall satisfaction with the teaching and learning process of nursing program $(\chi 2=2.110$, $\mathrm{P}=0.550$ ). Among the male students, $65.4 \%$ of the students were satisfied with the teaching and learning program whereas $68.7 \%$ of the female students were satisfied (Table 5).

\begin{tabular}{|c|c|c|c|c|c|c|c|}
\hline & & & \multicolumn{4}{|c|}{ Overall satisfaction with the teaching and learning process of the nursing program } & \multirow[t]{2}{*}{ Total } \\
\hline & & & Not satisfied & Somehow satisfied & Satisfied & Extremely satisfied & \\
\hline \multirow[t]{4}{*}{ Gender } & Male & Count & 0 & 30 & 68 & 6 & 104 \\
\hline & & $\%$ & $0.0 \%$ & $28.8 \%$ & $65.4 \%$ & $5.8 \%$ & $100.0 \%$ \\
\hline & Female & Count & 2 & 42 & 123 & 12 & 179 \\
\hline & & $\%$ & $1.1 \%$ & $23.5 \%$ & $68.7 \%$ & $6.7 \%$ & $100.0 \%$ \\
\hline \multirow[t]{2}{*}{ Total } & & Count & 2 & 72 & 191 & 18 & 283 \\
\hline & & $\%$ & $0.7 \%$ & $25.4 \%$ & $67.5 \%$ & $6.4 \%$ & $100.0 \%$ \\
\hline
\end{tabular}

Table 5: Students' gender and the level of satisfaction with the teaching process of nursing program. 
Citation: Kabanya CN, Karani AK, Mirie W (2017) Socio-Demographic Determinants of Satisfaction with Training Process among Final Year Nursing Students at Kenya Medical Training College. Adv Practice Nurs 2: 128. doi:10.4172/2573-0347.1000128

Page 4 of 6

\section{Sources of information about nursing career}

The students were asked to mention their sources of information about nursing career. The main source of the information as stated by $36.3 \%$ of the students was from personal interaction with the nurses, $35.7 \%$ of the students had gotten information from their parents and relatives while $4.7 \%$ of the students obtained information from books and pamphlets (Table 6).

\begin{tabular}{|l|l|l|}
\hline Sources & Number of students (N=300) & Percent (\%) \\
\hline Book and pamphlets & 14 & 4.7 \\
\hline Media (TV, radio/newspaper) & 48 & 16.0 \\
\hline Personal interaction with nurses & 109 & 36.3 \\
\hline Career guidance teacher & 11 & 3.7 \\
\hline Parents and relatives & 107 & 35.7 \\
\hline Other sources & 11 & 3.7 \\
\hline
\end{tabular}

Table 6: Student sources of information about nursing career.

\section{Source of influence to join nursing training}

To join nursing career, majority of the students (42.3\%) were influenced by a Nurse role model, $36.0 \%$ of the students were influenced by parents and relatives, $9.3 \%$ were influenced by peers and friends, $4.3 \%$ were influenced by teachers and school counselors while $4.0 \%$ were influenced by other factors (Table 7 ).

\begin{tabular}{|l|l|l|}
\hline Sources influencing & Number of students & Percent (\%) \\
\hline Peers and friends & 28 & 9.3 \\
\hline Parents and relatives & 108 & 36.0 \\
\hline Teachers and school counselors & 13 & 4.3 \\
\hline Nurse role models & 127 & 42.3 \\
\hline Personal influence & 12 & 4.0 \\
\hline Others & 12 & 4.0 \\
\hline
\end{tabular}

Table 7: Sources that influenced the students to join nursing training.

\section{Effect of the sources about nursing career and the students overall satisfaction with the teaching process of the nursing program}

The students' information sources of the nursing career had a significant association on the students' satisfaction with the teaching and learning process of the nursing program $(\chi 2=63.31, P=0.000)$. Most of the students, $45.5 \%$ who had learnt about nursing from career guidance teachers were extremely satisfied with the teaching and learning program. $74.5 \%$ of those who had gotten information about nursing career from personal interaction with nurses were satisfied with the nursing teaching and learning program while $58.3 \%$ of the students who got to learn about nursing career from books and pamphlets were satisfied with the teaching and learning program (Table 8).

\begin{tabular}{|c|c|c|c|c|c|c|}
\hline \multirow[b]{2}{*}{ Source about nursing career } & & \multicolumn{4}{|c|}{$\begin{array}{l}\text { Overall satisfaction with the teaching and } \\
\text { learning process of the nursing program }\end{array}$} & \multirow[t]{2}{*}{ Total } \\
\hline & & Not Satisfied & Somehow satisfied & Satisfied & Extremely satisfied & \\
\hline \multirow[t]{2}{*}{ Books and pamphlets } & Count & 0 & 4 & 7 & 1 & 12 \\
\hline & $\%$ & $0.00 \%$ & $33.30 \%$ & $58.30 \%$ & $8.30 \%$ & $100 \%$ \\
\hline \multirow[t]{2}{*}{ Media (TV, radio/newspapers) } & Count & 0 & 15 & 29 & 2 & 46 \\
\hline & $\%$ & $0.00 \%$ & $32.60 \%$ & $63.00 \%$ & $4.30 \%$ & $100 \%$ \\
\hline \multirow[t]{2}{*}{ Personal interaction with nurses } & Count & 0 & 22 & 76 & 4 & 102 \\
\hline & $\%$ & $0.00 \%$ & $21.60 \%$ & $74.50 \%$ & $3.90 \%$ & $100 \%$ \\
\hline \multirow[t]{2}{*}{ Career guidance teachers } & Count & 0 & 2 & 4 & 5 & 11 \\
\hline & $\%$ & $0.00 \%$ & $18.20 \%$ & $36.40 \%$ & $45.50 \%$ & $100 \%$ \\
\hline \multirow[t]{2}{*}{ Parents and relatives } & Count & 0 & 27 & 69 & 6 & 102 \\
\hline & $\%$ & $0.00 \%$ & $26.50 \%$ & $67.60 \%$ & $5.90 \%$ & $100 \%$ \\
\hline \multirow[t]{2}{*}{ Others } & Count & 1 & 2 & 6 & 0 & 9 \\
\hline & $\%$ & $11.10 \%$ & $22.20 \%$ & $66.70 \%$ & $0.00 \%$ & $100 \%$ \\
\hline \multirow[t]{2}{*}{ Total } & Count & 1 & 72 & 191 & 18 & 282 \\
\hline & $\%$ & $0.40 \%$ & $25.50 \%$ & $67.70 \%$ & $6.40 \%$ & $100 \%$ \\
\hline
\end{tabular}

Table 8: Students' sources of information on nursing career and the level of satisfaction with the teaching process of nursing program. 


\section{Learners' involvement in extra-curriculum activities in the college}

When they are in college, $48.3 \%$ of the learners were involved in extra-curriculum activities. These activities include; Sports like football, rugby, volleyball, handball, basketball, hockey, lawn tennis, table tennis, scrabble, badminton. Games like Athletics. Other activities like charitable work for example, visiting prisoners and children homes, participating in outreach services organized by the hospitals, participating in hospital meetings and also setting the immunization group. They were also involved in clubs like counseling.

Regarding the extent to which the learners participation in extracurriculum activities contributed to their overall satisfaction with college experience, $13.0 \%$ of the learners felt that the activities extremely contributed to their overall satisfaction, $14.3 \%$ stated that it slightly contributed, 32.75 stated participation in the activities moderately contributed to their satisfaction while $40 \%$ of the learners felt that it did not contribute to their overall satisfaction at all (Figure $1)$.

The extent to which the learners participated in the extracurriculum activities had significant influence $(\mathrm{r}=0.143, \mathrm{P}=0.026)$ on their satisfaction in with the teaching and learning process of the nursing program. Students who felt that their participation in the extra-curriculum activities had contributed to their satisfaction with college experience were satisfied with the overall teaching and learning process (Table 9).

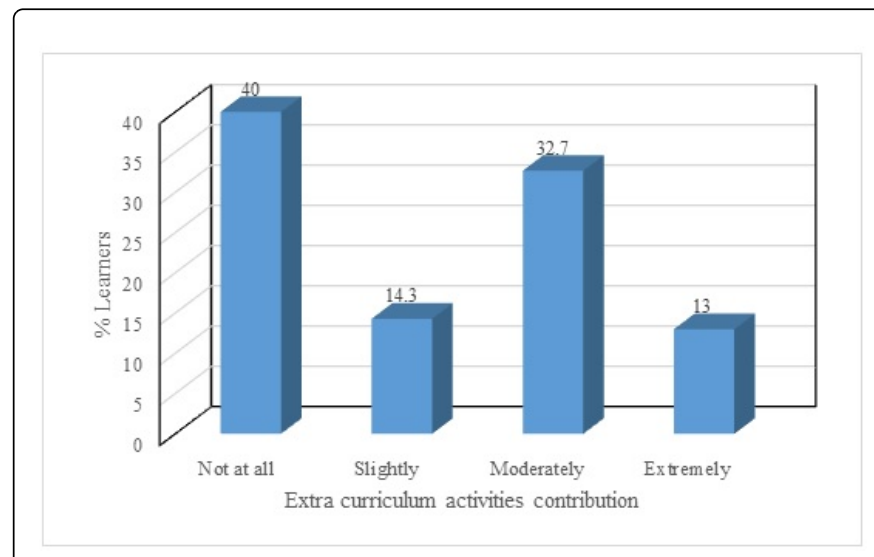

Figure 1: Extent to which learners' participation in extracurriculum activities contributed to overall satisfaction with college experience.

\begin{tabular}{|l|l|l|l|}
\hline & & $\begin{array}{l}\text { Extent to which participation in these activities } \\
\text { contributed to overall satisfaction with college } \\
\text { experience }\end{array}$ & $\begin{array}{l}\text { Overall satisfaction with the teaching } \\
\text { and learning process of the nursing } \\
\text { program }\end{array}$ \\
\hline $\begin{array}{l}\text { To what extent has your participation in these } \\
\text { activities contributed to your overall satisfaction } \\
\text { with college experience }\end{array}$ & r-value & 1 & $0.143^{*}$ \\
\hline & P-value & & 0.026 \\
\hline & N & 252 & 242 \\
\hline $\begin{array}{l}\text { What is your overall satisfaction with the teaching } \\
\text { and learning process of the }\end{array}$ & r-value & $0.143^{*}$ & 1 \\
\hline & P-value & 0.026 & \\
\hline & N & 242 & 283 \\
\hline
\end{tabular}

Table 9: Correlation result showing relationship between participation in extra-curriculum. ${ }^{*}$ Correlation is significant at the 0.05 level (2-tailed).

\section{Discussion}

The student factors that influenced satisfaction with teaching and learning in nursing training were identified from the study. In the study, $90 \%$ of the students were Christians who were satisfied with their training in nursing. Religion is closely associated with helping relationships. This concurs with a study by Pollard et al. [10] which indicated that helping individuals was found to provide nurses with great satisfaction. According to Dal et al. [11] nursing is a sacred profession where the need to help others emerged as the main motive of some students aspiring to join nursing. The gender of the students did not affect their overall satisfaction with teaching and learning program. These findings are consistent with other studies (Robins et al. [12], Ziae et al. [13], Tessema et al. [14], Ansari [9], Espeland et al. [15]). However, even with absence of significant differences in satisfaction according to gender, the trend of males and females reporting satisfaction was not stable. This could be due to the fact that women are more lenient in their ratings than male students Tessema et al [14].

Information sources regarding the nursing career had a significant association with student's satisfaction with the teaching and learning process $p=0.000$. Students who entered into the training with adequate information about the career and what to expect during the training were extremely satisfied with the teaching and learning process. The students who got the information from the career guidance teachers were more satisfied than those who got the information from nurses or parents and relatives. Career guidance teachers are likely to give unbiased information about a career hence leaving the student to make an informed career choice.

The involvement of learners in the extra curriculum activities influenced the student's satisfaction positively where $60 \%$ of the learners were satisfied with overall teaching and learning process. Students who felt that their participation in the extra-curriculum activities had contributed to their satisfaction with college experience 
Citation: Kabanya CN, Karani AK, Mirie W (2017) Socio-Demographic Determinants of Satisfaction with Training Process among Final Year Nursing Students at Kenya Medical Training College. Adv Practice Nurs 2: 128. doi:10.4172/2573-0347.1000128

Page 6 of 6

were satisfied with the overall teaching and learning process. These findings are consistent with a study Deshields et al. [16] who argued that students who have a positive college experience will be more satisfied than those students who do not have a positive experience.

The entry grades into the training of nurses were found to have some influence on the satisfaction of the students while in training. The students who had the highest scores in KCSE (A-) were somehow satisfied with the teaching and learning process while those who scored lower were satisfied with the teaching and learning process in the nursing training. These findings are consistent with the findings of a study by Robinson et al [12]. A probable explanation to this could be that the expectations of those with higher entry grades may not have been met in the teaching and learning process of nursing, or they did not have adequate information on the careers that existed to help them make informed choices.

\section{Conclusion}

The student related factors that influenced their satisfaction with the teaching and learning process included; student's information sources regarding the nursing career, the student's prior knowledge on nursing career roles and responsibilities and what to expect during training and involvement of learners in extra-curricular activities while in the college. However, there appears to be an inverse relationship between student's entry grades and level of satisfaction. Higher entry grades were associated with lower levels of satisfaction.

\section{Recommendations}

Career guidance in schools should be strengthened to help students in making informed career choices which are not influenced by the parents, relatives or peer pressure.

Extra-curricular activities including sports should be encouraged in the schools and training colleges to help the students exercise and relax.

\section{References}

1. Jaradeen N, Jaradat R, Safi AA, Tarawneh FA (2012) Student's satisfaction with nursing program. Bahrain Medical Bulletin 34.
2. Elliot KM, Shin D (2002) Student satisfaction an alternative approach to assessing this important concept. Journal of Higher Education Policy and Management 24: 197-209.

3. Liegler RM (1997) Predicting students satisfaction in Baccalacreate nursing programms testing a causal model. J Nurs Educ 36: 357-364.

4. Rognastad MK (2002) Recruitment to and motivation for nursing education to the nursing profession. J Nurs Educ 41: 321-325.

5. Zysberg L, Berry DM (2005) Gender and student's vocational choices in entering the field of nursing. Nurs Outlook 53: 193-198.

6. Ahmed I, Nawaz MM, Ahmed Z (2010) Does service quality affect student's performance? Evidence from institutes of higher learning. African journal of business management 4: 2527-2533.

7. Tiwaken SU, Caranto LC, David JJT (2015) The Real World: Lived Experiences of Student Nurses during clinical practice. International Journal of Nursing Science 5: 66-75.

8. Happell B (2008) Clinical experience in mental health nursing: Determining satisfaction and the influential factors. Nurse Educ Today 28: 849-855.

9. Ansari WE (2002) Student nurse satisfaction levels with their courses: part I -- effects of demographic variables Nurse Educ Today 22: 159-170.

10. Miers ME, Rickaby C, Pollard KC (2007) Career choices in health care: is nursing a special case? A content analysis of survey data. Int J Nurs Stud 44: 1196-1209.

11. Dal U, Arifoglu B, Razi G (2009) What factors influence students in their choice of nursing in North Cyprus. Procedia Social and Behavioural Sciences 1924-1930.

12. Robinson S, Murrells T, Clinton M (2006) Highly qualified and highly ambitious: implications for workforce retention of realizing the career expectations of graduate nurses in England. Human Resource Management Journal 16: 287-312.

13. Ziaee V, Ahmadinejad Z, Morravedji AR (2004) An Evaluation on Medical Students Satisfaction with Clinical Education and its Effective Factors: Med Educ 9: 8.

14. Tessema MT, Ready K, Yu WC (2012) Factors affecting college students' satisfaction with major curriculum: Evidence from Nine Years of Data. International Journal of Humanities \& social science 2: 34-44.

15. Espeland V, Indrehus O (2003) Evaluation of students' satisfaction with nursing education in Norway. J Adv Nurs 42: 226-236.

16. Deshields OW, Kara A, Kaynak E (2005) Determinants of business satisfaction and retention in higher education: applying Herzberg's twofactor theory. International Journal of Educational Management 19: 128-139. 